\title{
PENGUJIAN CAMPURAN FESES SAPI DAN KAPUR SEBAGAI BAHAN PENGHAMBAT SERANGAN RAYAP TANAH
}

\author{
Oleh \\ Teguh Pribadi', Murniaty² dan Ahmad Jauhari² \\ 1 Universitas PGRI Palangkaraya \\ 2Universitas Lambung Mangkurat Banjarbaru
}

\begin{abstract}
Utilization of natural materials as termicida of friendly with ecosystem be new trendsetter in termite control fields. Mixing of cowdung and limestone are tested their effectivity to slacken of subterranean termites infestation. Limestone is solved by water and cowdung in concentration (w/v) $05,25 \%, 50 \%$ and $75 \%$. Than this formulation is smeared on test stakes with $5 \times 5 \times 30 \mathrm{~cm}$ dimension. This efficacy is done with accelerated grave yard test methods.

Termites species that infestation of test stakes are Macrotermes gilvus Hagen. The test show that mixing of limestone and cowdung can prevent subterranean termites infestation on test stakes. The best termicida effect are result by mixing of limestone and cowdung in concentration (w/v) $50 \%$.
\end{abstract}

Key words : cowdung; limestone; subterranean termites; accelerated grave yard test; termicida effect

\section{PENDAHULUAN}

Rayap merupakan organisme perusak kayu yang utama dan paling ganas dibandingkan organisme perusak kayu lainnya (Sukartana, 1998). Kerugian material akibat serangan rayap tanah pada tahun 1995 hampir mendekati angka 1,67 trilyun (Nandika et al., 2003). Fenomena ini menstigmakan rayap sebagai musuh utama manusia dalam memperoleh produk-produk berselulosa. Berdasarkan fenomena ini Sukartana et al. (2002) menyatakan bahwa parameter kualitas keawetan kayu adalah kemampuannya dalam menghadapi penghancuran leh rayap.

Rayap tanah adalah kelompok rayap perusak kayu yang paling dominan. Dari seluruh spesies rayap yang ada di dunia ini, rayap tanah menyumbangkan anggota sebanyak $10 \%$ dari sekitar 2500 jenis rayap yang ada. Menurut laporan Haris (1971) yang dikutip oleh Rudi (1999), 64 jenis rayap dari 120 jenis rayap yang merusak bangunan atau $50 \%$-nya adalah rayap tanah.

Usaha pencegahan infestasi rayap tanah pada bangunan umumnya dilakukan dengan pemanfaatan bahan kimia sintetik yang bersifat racun bagi rayap. Namun, aplikasi termisida ini, tidak hanya beracun bagi rayap tetapi juga bagi lingkungan bahkan juga bagi manusia dan organisme lain. Efek toksik pada non targets organisms mengakibatkan kekacauan tata ekosistem yang ada melalui mekanisme pemutusan rantai makanan. Di 
sisi lain, termisida yang digunakan acapkali meninggalkan residu senyawa yang bersifat persisten dan meracuni lingkungan. Dimana dampak lebih lanjut dapat menghasilkan rayap dengan tipe baru yang lebih kebal terhadap paparan termisida dengan konsentarsi yang identik.

Berdasarkan pertimbangan-pertimbangan ini, akhir-akhir ini telah berkembang pemanfaatan bahan-bahan alamiah yang lebih ramah lingkungan sebagai material dasar termisida. Isolasi dan identifikasi komponen bioaktif zat-zat estraktif dari tumbuhan yang secara alamiah memiliki keawetan yang tinggi telah banyak dilakukan (Suparjana, 2000; Anisah, 2001; Syafii, 2002; Sari et al., 2004; Sari \& Hadikusumo, 2004). Teknologi antibiotik juga mulai dikembangkan dengan memanfatkan beberapa spesies entomopatogen (Sukartana et al., 2002).

Studi empirik menyatakan bahwa campuran ini biasa digunakan masyarakat pedesaan di Jawa untuk bahan pengawet anyaman bambu untuk dinding (getheg). Berdasarkan kecenderungan-kecenderungan di atas, maka kami mencoba keampuhan campuran feses sapi dan kapur dalam menghambat infestasi rayap tanah.

\section{BAHAN DAN METODE}

Obyek penelitian ini adalah rayap tanah yang terdapat di Arboretum Fakultas Kehutanan Universitas Lambung Mangkurat Banjarbaru. Bahan-bahan yang digunakan adalah feses sapi, kapur, balok kayu jabon, kertas karton, kawat kecil, paku payung dan perlengkapan tulis menulis dan dokumentasi. Peralatan yang digunakan antara lain neraca analitik, ember, saringan 120 mesh, amplas kayu, kuas, cangkul dan gelas ukur.

Sebelum dilakukan pengujian dilakukan survey pendahuluan dengan menanam balok kayu jabon dengan ukuran $5 \times 5 \times 30 \mathrm{~cm}$ yang dipendam sedalam kurang lebih 25 $\mathrm{cm}$ untuk memudahkan pengecekan pada lokasi yang lembab dan banyak bahan organik tanah selama beberapa hari untuk mengetahui keberadaan rayap tanah di lokasi tersebut. Setelah 30 hari pemendaman contoh uji dibongkar, rayap yang tertangkap diidentifikasi dan dikoleksi sebagai referensi.

Pembuatan formulasi larutan dengan terlebih dahulu mencampur feses sapi segar yang diencerkan lagi dengan air dalam perbadingan $1: 2$, kemudian menyaringnya dalam saringan 120 mesh. Air saringan inilah yang digunakan untuk membuat larutan koloid kapur dengan konsentrasi (perbandingan berat kapur dan volume pelarut atau w/v) $0 \%$, $25 \%, 50 \%$ dan $75 \%$. Sebagai pembanding digunakan pelarut air dalam konsentrasi yang sama.

Balok kayu jabon dengan ukuran $5 \times 5 \times 30 \mathrm{~cm}$ dihaluskan permukaannya dan disimpan dalam ruangan dalam suhu kamar selama 24 jam. Kemudian melabur contoh uji yang ada secara merata dan dikering udarakan selama 24 jam. Contoh uji yang tela kering, dikumpulkan berdasarkan perlakuaan, diikat dan di tengah-tengah ikatan tersebut disisipkan dengan kertas karton untuk meningkatkan daya tarik kedatangan rayap tanah pada contoh uji (La fage et al., 1983) dan diberi identitas untuk memudahkan pengecekan ulang saat pembongkaran nanti. Memendam contoh uji di daerah yang telah ditentukan dengan posisi tegak dan disisakan sepanjang $5 \mathrm{~cm}$ dari panjang contoh uji untuk tetap menyembul untuk memudahkan pemindaian lokasi dan pembongkaran selama 75 hari.

Diakhir pemendaman, semua contoh ui dibongkar dan derajat serangan rayap tanah pada contoh uji diskoring sesuai klasifikasi yang dibuat oleh Martawijaya \& Sumarni (1978) yang dikutip oleh Sumarni \& Roliadi (2002) seperti yang terdeskripsi pada Tabel 1. di bawah ini. 
Tabel 1. Derajat Serangan Rayap Tanah pada Contoh Uji setelah Pengujian

\begin{tabular}{|c|l|c|}
\hline No. & \multicolumn{1}{|c|}{ Kondisi Kayu yang Diserang } & Derajat Serangan (\%) \\
\hline 1 & Tidak ada serangan atau utuh & 100 \\
\hline 2. & Serangan ringan dan dangkal & 90 \\
\hline 3. & Serangan dangkal & 70 \\
\hline 4. & Serangan hebat & 40 \\
\hline 5. & Serangan sangat hebat atau hancur & 0 \\
\hline
\end{tabular}

Sumber : Martawijaya \& Sumarni (1978) yang dikutip oleh Sumarni \& Roliadi (2002)

\section{ANALISIS DATA}

Penelitian ini menggunakan percobaan faktorial dengan rancangan dasar rancangan acak lengkap. Percobaan ini terdiri dari 2 faktor yaitu jenis pengencer dan konsetrasi larutan. Yang masing-masing factor jenis pengencer yang terdiri dari 2 taraf (larutan feses sapi dan air) dan faktor konsentrasi yang terdiri dari empat taraf yaitu ; $0 \%$, $25 \%, 50 \%$ dan $75 \%$. Masing-masing perlakuan diulang sebanyak 5 kali. Interaksi antar masing-masing faktor diuji lagi dengan analisis pengaruh sederhana, jika interaksi berpengaruh nyata (Steel \& Torrie, 1995).

\section{HASIL DAN PEMBAHASAN}

\section{A. Identifikasi Rayap Tanah Penyerang Contoh Uji}

Rayap tanah yang tertangkap dan dikumpulkan kemudian dideterminasi berdasarkan kunci determinasi yang dibuat oleh Tarumingkeng (1971) dan pencocokan foto morfologi spesimen dengan foto yang terdapat dalam Nandika et al. (2003), maka rayap yang menyerang contoh uji adalah rayap jenis Macrotermes gilvus Hagen (Termitidae : Isoptera). Identifikasi ini didasarkan pada morfologi kasta prajurit, Karena kasta ini memiliki ciri yang lebih khas dibandingkan dengan kasta lain, terutama dalam morfologi, bentuk dan ukuran, kepala dan mandible. berikut ini.

Gambar dari rayap tangkapan setelah pengujian dapat dilihat pada Gambar 1,

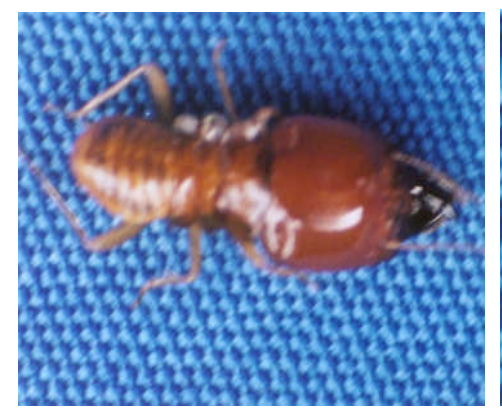

(A)

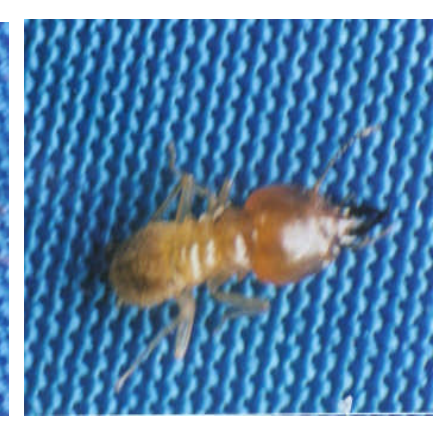

(B)

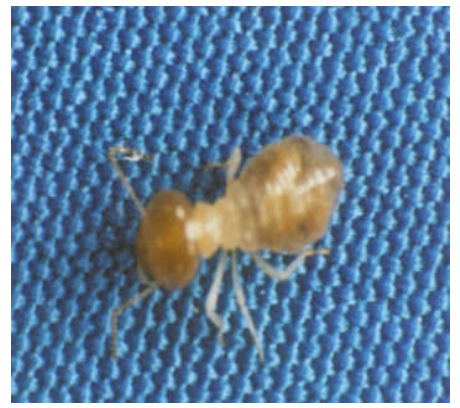

(C)

Keterangan

(A)

(B)

Kasta Prajurit makro M. gilvus Hagen hasil tangkapan setelah pengujian lapangan

Kasta Prajurit mikro M. gilvus Hagen hasil tangkapan setelah pengujian lapangan

(C)

Gambar 1. Rayap hasil tangkapan setelah pengujian. 
Tarumingkeng (1971) menyatakan bahwa M. gilvus Hagen adalah jenis rayap yang berukuran terbesar di Kawasan Asia Tenggara. Tersebar diseluruh Asia Tenggara, pada tempat-tempat sampai ketinggian 800 mdpl. M. gilvus Hagen memilik 2 ukuran kasta prajurit (dimorfis). Jenis ini termasuk jenis rayap yang umum dan mudah dijumpai di sekitar kita. Jenis ini mudah dikenali karena memiliki ukuran tubuh yang paling besar (prajurit makro) di antara semua jenis rayap. Koloni rayap ini pun mudah dijumpai di lahan kering seperti di pekarangan rumah penduduk dan lahan perkebunan atau kehutanan.

\section{B. Efikasi Larutan Feses sapi dan kapur sebagai termisida}

Hasil pengujian lapangan terhadap efikasi campuran feses sapi dan kapur dapat dilihat pada Tabel 2. di bawah ini.

Tabel 2. Rata-rata derajat Serangan Rayap Tanah pada Contoh Uji dalam Pengujian Lapangan yang Dipercepat

\begin{tabular}{|c|c|c|}
\hline \multirow{2}{*}{$\begin{array}{c}\text { Factor } B \\
\text { Konsentarsi (\%) }\end{array}$} & \multicolumn{2}{|c|}{$\begin{array}{c}\text { Faktor A (Jenis Pengencer) } \\
X \pm D^{*}(\%)\end{array}$} \\
\cline { 2 - 3 } & Air & Feses Sapi \\
\hline 0 & $30 \pm 30 \mathrm{e}$ & $86 \pm 8,94 \mathrm{~b}$ \\
\hline 25 & $62 \pm 21,68 \mathrm{~d}$ & $74 \pm 20,49 \mathrm{c}$ \\
\hline 50 & $78 \pm 10,95 \mathrm{c}$ & $96 \pm 5,48 \mathrm{a}$ \\
\hline 75 & $74 \pm 8,94 \mathrm{c}$ & $80 \pm 22,36 \mathrm{c}$ \\
\hline
\end{tabular}

Catatan: 1. Nilai rata-rata pada baris yang diiukti dengan haruf capital yang sama berarti tidak berbeda nyata $(n=5)$.

2. Nilai rata-rata pada kolom yang diikuti oleh huruf kecil yang sama berarti tidak berbeda nyata $(n=5)$

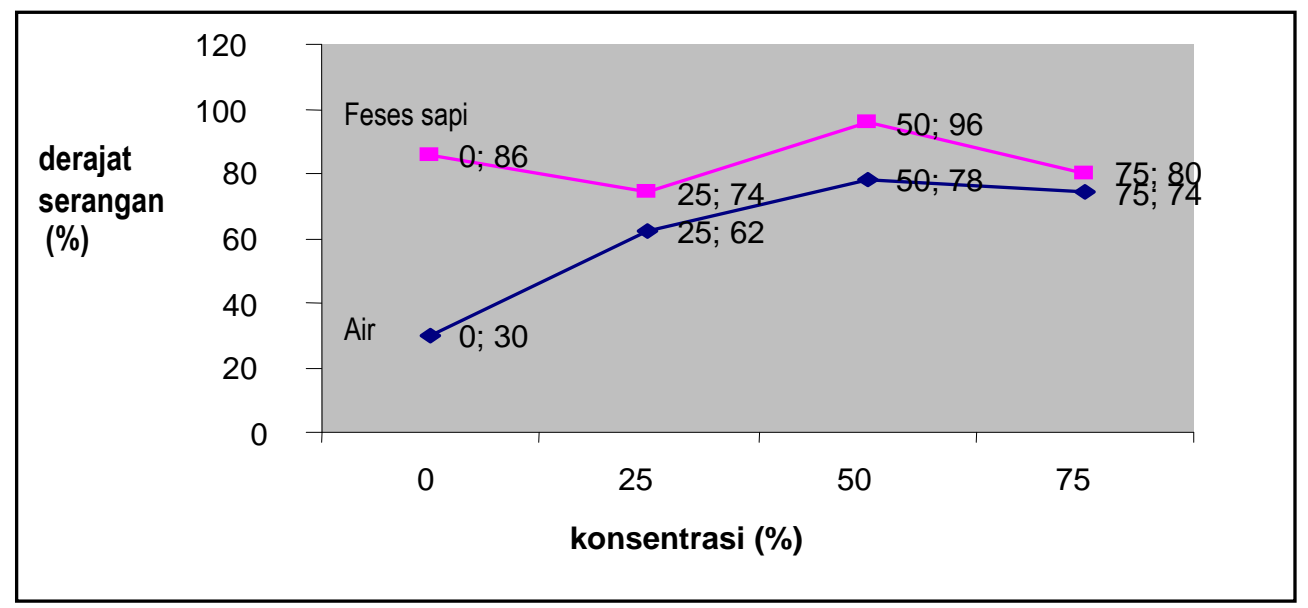

Gambar 4. Hubungan antara derajat serangan pada contoh uji dengan konsentrasi larutan untuk masingmasing perlakuan

Berdasarkan pada Tabel 2 dan Gambar 4 di atas dapat dilihat bahwa masingmasing perlakuan memberikan pengaruh yang berbeda-beda. Penambahan feses sapi pada kapur menghasilkan efek termisida yang lebih baik dibandingkan kapur dalam air saja. Derajat serangan tertinggi yaitu $96 \%$ yang dihasilkan oleh perlakuan feses sapi dan kapur dalam konsentrasi $50 \%$. Disusul oleh feses sapi saja dengan derajat serangan sebesar $86 \%$. Kelompok berikutnya adalah feses sapi dengan kapur dalam konsentarsi 75 $\%$ dan $25 \%$ serta kapur yang dilarutkan dalam air dengan konsentrasi $50 \%$ dan $75 \%$ 
yang masing-masing menghasilkan derajat serangan sebesar $80 \%, 74 \%, 78 \%$ dan 74 $\%$. Berikutnya adalah kapur yang dilarutkan dalam air dengan konsentrasi $25 \%$ yang menghasilkan derajat serangan sebesar $62 \%$. Kontrol pada percobaan ini memberikan derajat serangan sebesar $30 \%$, yang secara statistik memberikan pengaruh berbeda dengan masing-masing perlakuan di atas. Berdasarkan analisis pengaruh sederhana perlakuan yang memberikan pengaruh adalah interaksi jenis pengencer dalam konsentrasi $0 \%$ dan jenis konsentrasi pada pengencer feses sapi.

Efek toksik yang mengakibatkan pemberian feses sapi dan kapur menghasilkan efek menolak rayap diduga disebabkan oleh 3 hal yaitu ; Pertama, proses fisiologis dalam usus rayap terganggu selama proses pencernaan. Hal ini sesuai pendapat Sari et al. (2004) yang menyatakan bahwa mortalitas rayap disebabkan adanya senyawa tertentu yang mematikan protozoa sebagai simbion rayap dalam proses dekomposisi selulosa di dalam usus rayap. Dimana bila protozoa mati maka aktivitas enzim selulose yang dikeluarkan oleh protozoa tersebut terganggu sehingga rayap tidak memperoleh makanan dan energi yang dibutuhkan dan akibatnya rayap kelaparan dan mati.

Kedua, kristal molekul kapur menyebabkan goresan pada kutikulanya. Akibatnya terjadi kerusakan pada komponen struktural membran sel rayap sehingga transpor nutrisi yang diperlukan rayap untuk kelangsungan hidupnya menjadi terganggu (Suparjana, 2000). Ketiga, terjadinya proses penyumbatan spirekal (lubang-lubang pada integumen) yang dapat menyebabkan kematian, karena rayap bernapas dengan spirekal (Tarumingkeng, 2001).

Mekanisme ini menurut Novizan (2002) dikarenakan kapur memiliki sifat stabil secara kimia, berbentuk kristal dan bersifat permanen. Sehingga menyebabkan rayap menghindari makanan yang dilapisi kapur sampai kapur tersebut terkelupas dari kayu

Di tambah lagi dengan kemampuan feses sapi (Manure) yang mengandung bahan aktif yang bersifat repelan (menolak) melalui baunya atau adanya mikroorganisme lain yang bersifat patogen yang menyebabkan sistem syaraf rayap mengalami kerusakan (Other, 1966 yang dikutip oleh Sari \& Hadikusumo, 2004). Atau adanya bakteri yang menghambat proses sintesa protein fungsi sel (integritas memban sel) yang berdampak ada kegagalan proses ganti kulit (ecdysis) selama instar (tahap perkembangan rayap) (Sastrodihardjo, 1996 yang dikutip oleh Sari et al. 2004). Mekanisme sifat anti rayap ini dapat berlangsung secara independen maupun simultan antar masing-masing sifat antirayap

Nurtjahja et al. (2003) menyatakan bahwa limbah feses sapi mengandung \pm 77 zat atau senyawa, dan kemungkinan di dalamnya terdapat senyawa toksik untuk hewan lain. Menurut laporan Basak \& Lee (2001) yang dikutip oleh Nurtjahja et al. (2003) tinja sapi yang segar pada perbandingan 1: 2 mampu mengendalikan (100\%) patogen cendawan akar mentimun (Cucumis sativus $L$ ) dari serangan root rot oleh Fusarium Soluni f. sp cucurbitae Synder \& Hansen, dan layu oleh F. oxysporus f.sp cucumerium Owen. Tinja sapi kemungkinan memiliki mekanisme pertahanan dan memberikan perlindungan pada bagian leher akar tanaman

Konsentrasi kapur $50 \%$ menghasilkan mortalitas yang lebih tinggi untuk masingmasing pengencer. Hal ini dikarenakan kapur merupakan koloid,tidak larut dalam air, maka untuk menembus pori kayu ia hanya melalui lubang terbuka saja. Bila konsentrasi sedikit maka yang masuk ke dalam pori didominasi oleh air dan bila terlalu pekat maka air tidak dapat mendorong kapur masuk lebih dalam. Diduga hubungan antara kapur kapur dan daya absorbsi kayu membentuk pola kuadratik. 
Diduga bahwa sekitar Arboretum Fakultas Kehutanan Universitas Lambung Mangkurat memiliki kepadatan populasi rayap tanah yang tinggi. Indikasi ini dilihat dari cepatnya contoh uji diserang dan tingkat serangan rayap yang tinggi. Beberapa contoh penelitian seperti yang dilakukan oleh Sukartana (1995) untuk mendegradasikan contoh uji diperlukan waktu sampai 14 minggu sedangkan pada percobaan ini cukup 75 hari (10 minggu sudah cukup bagi rayap untuk menghancurkan contoh uji yang dipendam). Bahkan, penelitian Pranggodi et al. (1983) dengan bahan yang diujikan sama yaitu kapur, ternyata waktu 6 bulan belum menunjukan tanda-tanda serangan pada contoh uji.

Perbedaan tingkat serangan pada percobaan ini dikarenakan: pertama, perbedaan jenis organisme penyerang kayu; kedua, metode penelitian atau metode pendekatan yang digunakan; dan ketiga, keadaan contoh uji (Sukartana. 1995). Selain itu menurut Pranggodi et.al. (1983) perbedaan ketersedian pilihan makanan di sekitar lokasi penelitian juga berpengaruh pada tingkat serangan rayap tanah.

Pada penelitian ini serasah yang banyak ditemukan adalah serasah yang berasal dari daun akasia (Accacia mangium) sehingga rayap diduga tidak terlalu menyukainya dan beralih kebentuk makanan lain (contoh uji). Walaupun pada musim kemarau, serangan terjadi cukup hebat karena lokasi di sekitar penelitian cukup lembab dan tanahnya memiliki kandungan liat yang relatif tinggi, sehingga mendukung aktivitas rayap.

Menurut Rudi (1999) perilaku makan rayap di lapangan tergantung pada tempat koloni tersebut berada dan jumlah populasi rayap yang menyerang. Di alam rayap dihadapkan banyak pilihan makanan dalam keadaan tersebut rayap akan memilih tipe makanan yang paling disukai, sedangkan sumber makanan lainnya ditinggalkan. Ini terlihat pada penelitian, karton yang digunakan untuk merangsang rayap sudah hancur terlebih dahulu baru contoh uji yang ada di dekatnya. Hal ini diperkuat dengan fakta bahwa hampir semua contoh uji diserang rayap, walaupun pada 3 ulangan pada perlakuan feses sapi dengan konsentrasi kapur $50 \%$ masih steril dari infestasi rayap tapi sisanya ada yang mulai diserang.

Jarak yang dekat $( \pm 1 \mathrm{~m})$ antar masing-masing contoh uji juga memperkuat dugaan ini. Sehingga rayap akan memilih makanan yang paling dekat dengannya. Mencoba untuk mencicipinya terlebih dahulu dan bila makanan itu tidak enak (mengandung bahan anti rayap) ia akan merubah jenis makanannya dengan tipe yang sesuai dengan selera rayap. Hal ini juga diperkuat oleh penelitian Bakti (2004) bahwa Rayap Coptotermes curvignathus Holmgren tidak menyerang patok kayu sawit. Hal ini mengindikasikan bahwa sebenarnya rayap tidak menyenangi kelapa sawit bila ditemukan jenis kayu lain. Tanaman akan mengalami serangan rayap apabila habitatnya aslinya terganggu dan kesediaan makanan kurang, maka rayap akan merubah jenis makanannya.

Perilaku makan rayap ini diduga karena peranan syaraf gustatory yang berperan besar dalam pengujian ini. Sementera itu faktor peran syaraf perasa olfactory dalam menemukan sumber makanan juga harus diperhatikan, karena rayap dan contoh uji diperkirakan jaraknya relatif jauh.

\section{DAFTAR PUSTAKA}

Anisah, L.N. 2001. Zat Estraktif Kayu Tanjung (Mimusops elengi Linn) dan Kayu Sawo Kecik (Manilkara kauki Dubard) serta Pengaruhnya terhadap Rayap Tanah Coptotermes curvignathus Holmgren dan Jamur Pelapuk Schizophyllum commune Fries. Tesis Pascasarjana IPB, Bogor. Tidak diterbitkan. 
Bakti, Darma. 2004. Keanekaragaman Jenis Rayap pada Ekosistem Perkebunan Kelapa Sawit dan Hutan di Sekitarnya. Kultura (39) No 1. Fakultas Pertanian Universitas Sumatera Utara, Medan

La Fage, J.P, S-Y. Su, M.J.Jones \& GR. Esenther. 1983. A rapid Method for Collectig Large Number of Subterranean Termites from Wood. Socio-Biology 7(3) : $305-$ 309

Nandika, D., Y. Rismayadi \& F. Diba. 2003. Rayap Biologi dan Pengendalian. Muhammadiyah University Press UMS, Surakarta.

Novizan. 2002. Membuat dan Memanfaatkan Peptisida Ramah Lingkungan. Agro Media Pustaka, Jakarta.

Nurtjahja. E, S.D. Rumetor, JF.Salamena, E. Hermawan, S. Darwati \& S.M. Soenano. 2003 . Pemanfaatan Limbah Ruminansia untuk Mengurangi Pencemaran Lingkungan. http//www. Hayati_ipb. Com/users/Rudyct/pps 702/feses sapi-htm. Diakses pada 21 Mei 2004.

Pranggodi, B. Y.R. Mardikanto \& D. Nandika. 1983. Pengujian Efektivitas Kapur untuk Mencegah Serangan Rayap Subteran pada Bangunan. Laporan Penelitian. Institut Pertanian Bogor, Bogor

Rudi. 1999. Preferensi Makan Rayap Tanah Coptotermes curvignathus Holmgren (Isoptera : Rhinotermitidae) terhadap Delapan Jenis Kayu Bangunan. Tesis Pascasarjana IPB, Bogor. Tidak diterbitkan

Sari, L \& S.A. Hadikusumo. 2004. Daya Racun Estraktif Kulit Pucung terhadap Rayap Kayu Kering Cryptotermes cynocephalus Light. Jurnal IImu dan Teknologi Kayu Tropis 2(1). Masyarakat Peneliti Kayu Indonesia. UPT Litbang Biomaterial LIPI, Bogor

Sari, R.K, W. Syafii, K. Sofyan \& M. Hanafi. 2004. Sifat Antirayap Resin damar Mata Kucing dari Shorea javanca K. et L. Jurnal Ilmu dan Teknologi Kayu Tropis 2(1). Masyarakat Peneliti Kayu Indonesia. UPT Litbang Biomaterial LIPI, Bogor

Steel, R.G.D \& J.H.Torrie. 1995. Prinsip dan Prosedur Statistika, Suatu Pendekatan Biometrik. Terjemahan Bambang Sumantri. Penerbit P.T. Gramedia, Jakarta

Sukartana, P. 1995. Daya Tahan Alami 30 jenis Kayu terhadap rayap tanah Macrotermes gilvus Hagen; Suatu Uji Lapang yang Dipercepat. Jurnal Penelitian Hasil Hutan 13(2):71-76. Pusat Penelitian dan Pengembangan Kehutanan, Bogor.

1998. Introducing Test Metodes for The Subterranean Termites Coptotermes curvignathus (Isoptera : Rhinotermitidae) in Laboratory. Proceeding of Second International Wood Science Seminar. 6 - 7 November 1998. JSPS LIPI Core University Program in The Field of Wood Sciencs. R \& D Center for Applied Phyisics LIPI Indonesia dan Wood Research Institut Kyoto University Japan, Serpong - Indonesia

; R. Rushelia \& W. Rumini. 2002. Termicidal Perfomance of an Entomopathogenic Fungus and Bacterium to Subterranean Termite Coptotermes curvignathus Holmgren (Isoptera : Rhinotermitidae). Jurnal Teknologi Hasil Hutan 15(1). Fakultas Kehutanan Institut Pertanian Bogor, Bogor.

Suparjana, T.B. 2000. Kajian Toksisitas beberapa Fraksi Estraktif Kayu Sonokembang (Ptrerocarpus indicus Willd) dan Nyatoh (Palaqiun gutta Boudi) terhadap Rayap Tanah dan Jamur Pelapuk Kayu. Draft Tesis Pascasarjana Institut Pertanian Bogor, Bogor, Tidak dipubliksikan 
Syafii, W. 2000. Sifat Anti Rayap Zat Estraktif Beberapa Jenis Kayu Daun Lebar Tropis. Buletin Kehutanan (42). Fakultas Kehutanan Universitas Gadjah Mada, Yogyakarta.

Tarumingkeng, R.C. 1971. Biologi dan Pengenalan Rayap Perusak Kayu di Indonesia. Laporan No 138. Depertemen Pertanian Dirjen Kehutanan Lembaga Penelitian Hasil Hutan, Bogor

R.C. 2001. Serangga dan Lingkungan. www. Hayati_ipb. Com. Diakses pada 25 Januari 2004 